4. Про зареєстровані кримінальні правопорушення та результати їх досудового розслідування. Генеральна прокуратура України. URL: http://www.gp.gov.ua/ua/stat.html.

5. Довідка про злочини, вчинені в Україні за 2014-2019 рр.: службовий документ. Департамент аналітичної роботи та організації управління МВС України. Київ, 2019. 124 с.

6. Звіт МОМ «Боротьба з торгівлею людьми в Україні: співпраця та підтримка НУО» станом на 31 грудня 2019 року. URL: http://iom.org.ua/ua/protidiya-torgivli-lyudmi.

7. Левченко Е.Б. Предотвращение торговли людьми и эксплуатации детей : науч.-метод. пособие. Киев : Юрисконсульт, 2016. 210 с.

8. Висвітлення в 3МІ проблеми торгівлі людьми : посіб. для журналістів. Київ : Інтертехнологія, 2013. $64 \mathrm{c}$.

9. Витяг із Доповіді Державного департаменту США про торгівлю людьми від 12 червня 2007 р. Україна (контрольний список другої групи). URL: http://kiev.usembassy.gov/files/070612_ TIP_Report_2007_Ukr.html.

10. Смець О.М. Актуальні аспекти міжнародної протидії торгівлі людьми. Роль та місие ОВС у розбудові демократичної правової держави: сучасний стан, проблеми та шляхи вирішення : матеріали Міжнарод. наук.-практ. конф. (10 квіт. 2009 р.). Одеса : ОДУВС, 2009. С. 280-281.

11. Ситуація з торгівлею людьми в Україні. Нелегальне працевлаштування українців за кордоном. Протидія торгівлі людьми: законодавчі та нормативні акти зарубіжних держав : інформ.-аналіт. довід. URL: http://www.dcz.gov.ua/control/.

12.Протидія торгівлі людьми. Міжнародна організаиія 3 міграції. URL: http://www.iom.org.ua/index.php?page= catalog\&id=11.

13. Горбунова О. Досвід Міжнародної організацій з міграції в протидії торгівлі людьми. Актуальні питання запобігання і протидії торгівлі людьми : матеріали міжнарод. наук.-практ. конф. Київ : Акад. управління МВС; Харків : Права людини, 2010. С. 71-72.

14. Буряк М.Ю. Торговля людьми и борьба с ней: Криминологические и уголовно-правовые аспекты : дис. канд. юрид. наук: 12.00.08. Владивосток, 2005246 с.

15. Протидія торгівлі людьми. Міжнародна організація 3 міграції. 2019. URL: http://iom.org.ua/ua/protidiya-torgivli-lyudmi.

УДК 343.326

DOI https://doi.org/10.32844/2618-1258.2019.6.50

СІСЕЦЬКА А.В.

\title{
ДІЯЛЬНІСТЬ СЛУЖБИ БЕЗПЕКИ УКРАЇНИ ЩОДО ЗЛОЧИНІВ, ПОВ’ЯЗАНИХ ІЗ ТЕРОРИСТИЧНОЮ ДІЯЛЬНІСТЮ
}

У статті висвітлено рішення щодо необхідності забезпечення законних інтересів держави, суспільства, громадянина та людини. Було виявлено, що ключове місце у протидії виникнення терактів посідає Служба безпеки України. Стаття присвячена діяльності СБ України щодо злочинів із терористичною спрямованістю, їх порядку, труднощів, 3 якими стикаються співробітники при вирішенні покладених на них завдань, щодо попередження, своєчасного виявлення і запобігання посягань на інтереси держави та суспільства, протидії терористичній діяльності.

Згідно із Законом України «Про Службу безпеки України», а саме абзацу 2 статті 2 , в якій зазначено завдання СБ України, «до завдань Служби безпеки України також входить попередження, виявлення, припинення та розкриття злочинів проти миру i безпеки людства, тероризму, корупції та організованої злочинної діяльності у сфері управління і економіки та інших протиправних дій, які безпосередньо створюють загрозу життєво важливим інтересам України» [8]. Одне із завдань, а саме попередження, виявлення, припинення та розкриття тероризму, досліджене у цій статті.

Мудрого)

() СІСЕЦЬКА А.В. - студентка (Національний юридичний університет імені Ярослава 
Тероризм - це суспільно небезпечна діяльність, яка полягає у свідомому, цілеспрямованому застосуванні насильства шляхом захоплення заручників, підпалів, убивств, тортур, залякування населення та органів влади або вчинення інших посягань на життя чи здоров'я ні в чому не винних людей або погрози вчинення злочинних дій із метою досягнення злочинних цілей [1]. Здійснюється тероризм окремими особами, групою осіб, які виражають певні політичні, релігійні ідеї. 3 одного боку терор - це своєрідне самовираження до навколишнього світу та людей.

Тероризм є одним із методів вирішення проблем, але небезпечним для оточуючих, антигуманним способом в умовах зіткнення інтересів, поглядів політичного, соціального чи релігійного спрямування щодо несправедливості, нерівноправності. Тероризм - одне із найнебезпечніших явищ, яке ставить під загрозу як суспільне життя, так і державу загалом, посягає на громадську безпеку, цілісність і недоторканість. Небезпечним $\epsilon$ те, що терор спрямований не на одну людину, не на малу групу людей, а на масштабні маси, здійснюється у місцях великого скупчення людей (метро, вокзали). Від якого страждають як країни, в яких тривають збройні конфлікти, так і інші держави, більш захищені від терактів. Терор може бути як одним зі способів і засобів задоволення власних потреб посадових діячів чи інших осіб, які знаходяться в тіні.

Ключові слова: тероризм, терор, терористична діяльність, Служба безпеки України, терористичний акт, телекомунікаційні мережі.

The article is about the need for the protection of the legitimate interests of the state, suspension, community and people. In the course of the study, we found that the main and key role in counteracting the terrorist attacks is the Security Service of Ukraine. This article is devoted to the activities of the Security Council of Ukraine on crimes with a terrorist orientation, their order, the difficulties faced by employees in solving their assigned tasks, to prevent, timely identify and prevent encroachments on the interests of the state and society, counteract terrorist activity.

Terrorism is a socially dangerous activity that involves the deliberate, deliberate use of violence by hostage-taking, arson, murder, torture, intimidation of the population and authorities, or other harm to the life or health of innocent people or the threat of perpetrating criminal acts actions to achieve criminal goals [1]. Terrorism is committed by individuals, a group of individuals who express certain political, religious ideas. On the one hand, terror is a kind of self-expression for the world and people. Terrorism is one of the methods of solving problems, but dangerous for others, in an inhumane way in the face of conflicts of interest, views of political, social or religious orientation, about injustice, inequality.

Terrorism is one of the most dangerous phenomena that threatens both public life and the state as a whole, encroaching on public security, integrity and integrity. The most dangerous thing is that terror is directed not at one person, not at a small group of people, but at large masses, carried out in places of large crowd of people, such as subways, train stations and others. Afflicted, both in countries where armed conflicts continue and in other countries where they are more protected from acts of terrorism. Terror can be one way and means of meeting the needs of officials or others in the shadows.

Terrorism is one of the most unprincipled apparitions, but not the only preamble not only of the national, but of the holy, the threat - for the population, and for the state as a whole. It's possible to increase the strength of the terrorist acts and the nature of the circuit, stink me better, more unstable, like i'm all growing up and overturning in the mass of overwhelming.

Key words: terrorism, terror, terrorist activity, Security Service of Ukraine, Security Service of Ukraine, terrorist act, telecommunication networks.

Вступ. Тероризм - одне із найнебезпечніших явищ, яке $\epsilon$ не тільки бідою національною, а й світовою, загрозою і для населення, і для держав. Це засвідчили, зокрема, події у Парижі ввечері 13 листопада 2015 року, коли сталася серія терактів. Невідомі відкрили стрілянину в одному iз ресторанів 10 округу французької столиці. Три вибухи пролунали поруч зі стадіоном «Стад де 
Франс» під час футбольного матчу між збірними Франції та Німеччини, на якому був присутній президент Республіки Франсуа Олланд. Окрім того, на рок-концерті в театрі «Батаклан» невідомі захопили заручників. Загинуло 129 осіб. Терористичне угрупування «Ісламська держава» взяло на себе відповідальність за цю серію терористичних атак [5, с. 460]. Цікаво те, що серед 60 держав світу ці терористи визнали своїм ворогом й Україну. Після агресії Російської Федерації нині це питання набирає все більшої актуальності у світі. Наразі спостерігається посилення терористичних актів і зміна характеру цих дій, вони стають більш жорстокими, неодноманітними, все більше розростаються та перетворюються в масове заворушення. Протидіяти тероризму 3 кожним разом важче.

Постановка завдання. Метою статті є дослідження діяльності СБ України щодо злочинів терористичної спрямованості, огляд механізму запобігання, припинення та розслідування таких злочинів, акцентування уваги на проблемних питаннях, які перешкоджають ефективному розслідуванню.

Результати дослідження. Термін «тероризм» походить від латинського “terroro", що означає «страх, жах». Явище тероризму відоме людству з давніх-давен і першим, хто почав використовувати злочинну діяльність в такому руслі, було терористичне угрупування - секта секаріїв, яка діяла в Палестині в 66-73 pр. н.е. Важливим аспектом секарійської тактики було вчинення злочинної дії саме в епіцентрі «давки», яку вони визначали як «темрява натовпу», де не можливо було з'ясувати, хто ж реалізував злочинний замисел [2]. Після Першої світової війни європейські держави проводили політику залякування та знищення всіх, хто мислив по іншому. Була лише одна правильна думка, ідеологія, якої повинні були притримуватися всі - це явище називається державний тероризм.

Після Другої світової війни тероризм набрав обертів і трансформувався в міжнародний терор. Як зазначає С. Маделик, міжнародний тероризм - це форма політичної боротьби, яку використовують різні політичні рухи, партії, групи та інші організації, в основу діяльності яких покладено екстремізм і насилля для тиску на суб'єктів міжнародної діяльності з метою досягнення ними політичних цілей [5]. Такий терор вважався більш жорстоким, він супроводжувався масовими вбивствами, вибухами в людних місцях, захопленням заручників. Отже, тероризм існує 3 давніх-давен, розвивається, набирає обертів, йому все важче протидіяти. 3 одного боку терор - це жорстокий вияв і демонстрація власних поглядів, релігійної спрямованості, національної ідеології.

Існує велика кількість думок науковців у галузі права щодо визначення «тероризму». В. Антипенко визначає тероризм як застосування насильства для впливу шляхом залякування на недоторканність національних і наднаціональних інститутів, яке призвело до невинних жертв або настання суспільно-небезпечних наслідків, або таке, що утворює загрозу їх настання [3, с. 6]. Грунтовне визначення «тероризму» запропонував В. Петрищев: «Тероризм - це систематичне, соціально і політично вмотивоване, ідеологічно зумовлене використання насильства або погроз його застосування, за допомогою якого через залякування фізичних осіб здійснюється управління їх поведінкою у вигідному для тероризму напрямі і досягається визначена терористами мета» [7].

Відповідно до Європейської конвенції про боротьбу з тероризмом від 27 січня 1977 року тероризм - тяжкий злочин:

- пов'язаний із посяганням на життя, фізичну недоторканність або свободу осіб, які перебувають під міжнародним захистом, включаючи дипломатичних агентів;

- пов'язаний із викраданням людей, захопленням заручників або тяжким незаконним затриманням;

- 3 використанням бомб, гранат, ракет, автоматичної вогнепальної зброї або вибухових листів чи посилок, якщо це призводить до загрози особам;

- замах на вчинення будь-якого із вказаних злочинів або участь як співучасника особи, що вчиняє або намагається вчинити такий злочин [3].

У статті 258 Кримінального кодексу України (далі - КК України) зазначено: «Терористичний акт, тобто застосування зброї, вчинення вибуху, підпалу чи інших дій, які створювали небезпеку для життя чи здоров'я людини або заподіяння значної майнової шкоди чи настання інших тяжких наслідків, якщо такі дії були вчинені з метою порушення громадської безпеки, залякування населення, провокації воєнного конфлікту, міжнародного ускладнення, або з метою впливу на прийняття рішень чи вчинення або невчинення дій органами державної влади чи органами місцевого самоврядування, службовими особами цих органів, об'єднаннями громадян, юридичними особами, або привернення уваги громадськості до певних політичних, релігійних чи інших поглядів винного (терориста), а також погроза вчинення зазначених дій із тією самою метою» [4]. 
Явище тероризму не можливе без терористичної діяльності, тобто дій, потрібних задля вчинення терору, які можуть бути як одиночними, так і послідовно зв'язаними діями. 3 метою запобігання потуранню та сприянню злочину такі складники терору як втягнення у вчинення терористичного акту, публічні заклики до вчинення терористичного акту, створення терористичної групи чи терористичної організації, сприяння вчиненню терористичного акту, фінансування тероризму мають окремий склад злочину.

Боротьба з тероризмом - діяльність щодо запобігання, виявлення, припинення, мінімізації наслідків терористичної діяльності. Боротьба з тероризмом грунтується на таких принципах:

- законності та неухильного дотримання прав і свобод людини і громадянина;

- комплексного використання правових, політичних, соціально-економічних, інформаційно-пропагандистських та інших можливостей; пріоритетності попереджувальних заходів;

- невідворотності покарання за участь у терористичній діяльності;

- пріоритетності захисту життя і прав осіб, які наражаються на небезпеку внаслідок терористичної діяльності;

- поєднання гласних і негласних методів боротьби з тероризмом;

- нерозголошення відомостей про технічні прийоми і тактику проведення антитерористичних операцій, а також про склад їх учасників;

- єдиноначальності в керівництві силами і засобами, що залучаються для проведення антитерористичних операцій;

- співробітництва у сфері боротьби з тероризмом з іноземними державами, їх правоохоронними органами і спеціальними службами, а також з міжнародними організаціями, які здійснюють боротьбу з тероризмом [1].

Кабінет Міністрів України в межах своєї компетенції здійснює організаційну роботу, забезпечує ресурсами, засобами, необхідними для боротьби з терактами. До суб'єктів, які безпосередньо здійснюють боротьбу з тероризмом, належить Служба безпеки України - головний орган щодо протидії терору.

Згідно з частиною 1 статті 1 Закону України «Про Службу безпеки України» Служба безпеки України - це державний правоохоронний орган спеціального призначення, який забезпечує державну безпеку України [8]. Згідно Закону України «Про засади внутрішньої та зовнішньої політики» основним ії завданням є своєчасне виявлення, запобігання та нейтралізація реальних і потенційних загроз національним інтересам [9]. Основним завданням Служби безпеки України є захист державних інтересів, в які й включається боротьба з тероризмом. Це завдання виконують за допомогою здобутої контррозвідувальної та розвідувальної інформації шляхом використання методів і засобів оперативно-розшукової діяльності в межах, встановлених законом.

Щодо повноважень працівника, то вони мають право щодо перевірки документів, вимагати негайно припинити протиправні посягання, проводити огляд, гласні і негласні слідчі (розшукові) дії, застосовувати спеціальні засоби та зброю, здійснювати співробітництво з громадянами та інше.

Одним зі структурних елементів СБ України є органи військової контррозвідки. 3 метою гарантування непорушності прав людини законодавець вніс до оперативної діяльності відповідні обмеження застосування способів і методів: методи і засоби діяльності СБУ не повинні завдавати шкоди життю, здоров'ю, честі та гідності людей; для отримання інформації забороняється застосовувати технічні засоби, психотропні, хімічні та інші речовини, які пригнічують волю або завдають шкоди здоров'ю людей та навколишньому середовищу; забороняється залучати до виконання оперативно-розшукових завдань медичних працівників, священнослужителів, адвокатів, якщо особа, щодо якої вони мають здійснювати оперативно-розшукові заходи, є їх пацієнтом чи клієнтом [10].

Специфічною особливістю цього органу є його «обмежена прозорість». Порівняно з Національною поліцією СБ України не може бути настільки прозорою. 3 метою виконання на високому рівні покладених на неї завдань певна частина оперативної діяльності повинна залишатися таємною. Але й щодо негласної діяльності існують певні гарантії для осіб, наприклад заборона оперативним співробітникам застосовувати прослуховування, перехоплення, зберігання та інші види перехоплювання і нагляду за зв'язком, за винятком передбачених законом, наявність дозволів. Ці норми закріплені в міжнародних актах та документах, таких як ст. 12 Загальної декларації прав людини, ст. 8 Європейської конвенції про захист прав людини та основоположних свобод, ст. 17 Міжнародного пакту про громадянські та політичні права, ст.ст. 5, 14 Директиви Європейського Парламенту і Ради ЄС «Стосовно обробки персональних даних і захисту права на невтручання в особисте життя в телекомунікаційному секторі». 
В Конституції України закріплено право щодо таємниці листування та телефонних розмов, але допускаються винятки відповідно до законодавства. Мета їх обмеження полягає у запобіганні злочину чи під час розслідування справи, якщо інших джерел інформації встановити не вдалось; лише у випадках, зазначених у законі, та лише в інтересах національної безпеки, економічного інтересу та щодо прав людини. Ці положення відіграють особливе значення для запобігання та розслідування терористичної діяльності на території України.

Станом на 2019 рік Службою безпеки України було розкрито 35 злочинів, пов'язаних із терористичною діяльністю. 3 кожним роком терористичні акти території України трапляються все частіше, особливо в Луганській і Донецькій областях. Виникає необхідність використання телекомунікаційних мереж для розслідування цих злочинів. Таким правом наділена СБ України 3 метою отримання інформації в разі загрози вчинення терористичного акту або при проведенні антитерористичної операції.

Служба безпеки України має право проводити оперативно-технічні пошукові заходи в системах і каналах телекомунікацій, які можуть використовуватися терористами [1]. Згідно із Законом України «Про телекомунікації» оператори телекомунікацій зобов'язані встановлювати на своїх телекомунікаційних мережах технічні засоби, необхідні для здійснення уповноваженими органами оперативно-розшукових заходів, і забезпечувати функціонування таких технічних засобів, а також у межах своїх повноважень сприяти проведенню оперативно-розшукових заходів і недопущенню розголошення організаційних і тактичних прийомів їх проведення [11].

За загальним правилом зняття інформації з транспортних телекомунікаційних мереж відбувається згідно з положеннями ст. ст. 263, 265 Кримінального процесуального кодексу України на підставі ухвали слідчого судді за погодженням із прокурором. Відповідно до ст. 258 КПК України ніхто не може зазнавати втручання у приватне спілкування без ухвали слідчого судді [12]. Але в деяких країнах діє спрощена процедура щодо зняття, контролю та фіксування інформації з телекомунікаційних мереж. Прикладом такої країни $є$ Німеччина, яка у зв'язку із поширенням терористичних дій закріпила на законодавчому рівні прослуховування телефонів. Також одним із прикладів $є$ й Сполучені Штати Америки, які узаконили можливість прослуховування телефонних розмов без дозволу на те суду. Вони мають право прослуховувати не тільки своїх громадян, а й іноземців. Цими правами користується Агентство національної безпеки США, повноваження якого досить широкі, що дозволяє здійснювати безпосереднє прослуховування, аналіз списку телефонних дзвінків, відомостей щодо геолокації та іншої інформації, яка дає змогу дізнатися, чи належить особа до незаконного угрупування.

Висновки. Слідчим та оперативникам нечасто вдається встигнути отримати дозвіл суду на прослуховування телекомунікаційних мереж, що значно сповільнює хід справи та унеможливлює вчасне запобігання злочинним діям, пов'язаним із терористичною діяльністю. Виникає питання, чи є доцільним обов'язкове отримання дозволу суду для негласних слідчих (розшукових) дій щодо злочинів, пов'язаних із терористичною діяльністю? На думку автора, ця заборона перешкоджає вирішенню основного завдання КПК України, закріпленого в статті 2, в якій зазначається, що завданнями кримінального провадження є захист особи, суспільства та держави від кримінальних правопорушень, охорона прав, свобод та законних інтересів учасників кримінального провадження, а також забезпечення швидкого, повного та неупередженого розслідування i судового розгляду з тим, щоб кожний, хто вчинив кримінальне правопорушення, був притягнутий до відповідальності в міру своєї вини, жоден невинуватий не був обвинувачений або засуджений, жодна особа не була піддана необгрунтованому процесуальному примусу і щоб до кожного учасника кримінального провадження була застосована належна правова процедура [12]. Тому українське законодавство потребує визначення тимчасових повноважень щодо зняття інформації 3 транспортних телекомунікаційних мереж без судової ухвали для запобігання вчиненню та розслідування злочинів, пов'язаних із тероризмом.

\section{Список використаних джерел:}

1. Про боротьбу з тероризмом : Закон України від 20.03.2003 року № 638- IV// Відомості Верховної Ради України, 2003. № 25. Ст. 180.

2. Історичні витоки та еволюція тероризму / С.М. Маделик // Проблеми міжнародних відносин : Зб. наук. пр.1-ше вид. К. : КиМУ. 2010. С. 327-339.

3. Про ратифікацію Європейської конвенції про боротьбу з тероризмом від 17 січня 2002 року № 2990-III. URL: http://zakon3.rada.gov.ua/laws/show/994_331.

4. Кримінальний кодекс України : Закон України 5 квітня 2001 року № 2341-III. URL: https://zakon.rada.gov.ua/laws/show/2341-14. 
5. Тероризм як засіб дестабілізації державної влади // Актуальні проблеми державно-правового розвитку України в контексті євроінтеграційних процесів : матеріали міжнарод. наук.-практ. конф., присвяч. 20-річчю Конституції України; м. Запоріжжя, 23-24 червня 2016 р. / редкол.: С.К. Бостан (відпов. ред.), Р.М. Максакова, Ю.В. Філей.Запоріжжя : Просвіта, 2016. С. 460-463.

6. Гуляєв В.П. Тероризм як загроза сучасного суспільства / В.П. Гуляєв. URL: http://www.nbuv.gov.ua/old_jrn/soc_gum/domtp/2010_1/Gyljaev.pdf.

7. Хміль Г.А. Природний, техногенний та екологічний ризики: аналіз, оцінка, управління / Г.А. Хміль. URL: http://pidruchniki.com/72385/ ekologiya/prirodniy_tehnogenniy_ta_ekologichniy_ riziki_analiz_otsinka_upravlinnya.

8. Про Службу безпеки України : Закон України від 25 березня 1992 року № 2229-XII. URL: http://zakon3.rada.gov.ua/laws/show/2229-12.

9. Про засади внутрішньої та зовнішньої політики : Закон України від 1 липня 2010 року № 2411-VI. URL: https://zakon.rada.gov.ua/laws/show/2411-17.

10. Методи і засоби виконання завдань СБУ. URL: https:// ssu.gov.ua/ua/pages/38.

11. Про телекомунікації : Закон України від 18 листопада 2003 року № 1280-IV // Відомості Верховної Ради. 19 березня 2004 р. № 12. Ст. 155.

12. Кримінальний процесуальний кодекс України : Закон України від 13 квітня 2012 року станом на 7 жовтня 2014 року // Офіиійний сайт Верховної Ради Украӥни. URL: http://zakon2.rada.gov.ua.

УДК 343.611

DOI https://doi.org/10.32844/2618-1258.2019.6.51

СКОК С.Г.

\section{ДО ПИТАННЯ ПРО КВАЛІФІКАЦІЮ УМИСНИХ ВБИВСТВ У РАЗІ КОНКУРЕНЦІЇ КРИМІНАЛЬНО-ПРАВОВИХ НОРМ}

У статті досліджено особливості кваліфікації умисних вбивств у разі конкуренції кримінально-правових норм та конкретизовано, що конкуренція кримінально-правових норм є нормальною ознакою кодифікованого законодавства і свідчить про урахування законодавцем типових, але значною мірою специфічних ознак злочинних проявів, і засвідчує виділення конкретизованих норм із більш загальних норм, якими встановлена відповідальність за злочин, виписаний законодавцем у загальному (типовому) вигляді. Наявність у КК України двох або більше норм, спрямованих на захист одних і тих же об'єктів, є їх конкуренцією. Якщо злочин передбачено загальною і спеціальною нормами, сукупність злочинів відсутня, і кримінальна відповідальність настає за спеціальною нормою. Прикладом спеціальної норми щодо ст. 115 КК України (умисне вбивство) як загальної норми може бути ст. 379 КК України (посягання на життя судді, народного засідателя чи присяжного у зв'язку з їхньою діяльністю, пов'язаною зі здійсненням правосуддя). 3'ясовано, що аналіз судово-слідчої практики показує, що умисне вбивство, вчинене у стані сильного душевного хвилювання, або умисне вбивство у випадку перевищення меж необхідної оборони або в разі перевищення заходів, необхідних для затримання злочинця, також іноді вчиняються з особливою жорстокістю, також мають характер особливого мучення. Зроблено висновок про те, що якщо у скоєному діянні наявні дві або більше кваліфікуючі ознаки, то всі вони повинні бути згадані в обвинуваченні і вироку суду. Вчинені дії в такому випадку не утворюють сукупності злочинів, оскільки у скоєному діянні мають місце лише ознаки одного одиничного злочину. Наявність декількох кваліфікуючих ознак має враховуватися під час призначення покарання, посилюючи його. Отже, наявність двох або більше

(C) СКОК С.Г. - здобувач (Науково-дослідний інститут публічного права) 